\title{
Pattern of Cytokine Production by T Cells from Adolescents with Asthma in Remission, after Stimulation with Dermatophagoides farinae Antigen
}

\author{
TAKESHI NOMA, IZUMI YOSHZAWA, KUNITERU KOU, TADASHI NAKAJIMA \\ YUYTAKA KAWANO, MASAHIKO ITOH, KUNIO ICHIKAWA, TOKUKO MUKOUYAMA, \\ MINORU BABA, AND JUNICHI YATA \\ Department of Pediatrics, Saitama Medical School, Saitama. Japan /T.N., I.Y., K.K., T.N.. Y.K., M.B.J, \\ Departments of Pediatrics. Doai Memorial Hospital [K.I., T.M.J and Tokyo Medical and \\ Dental University /J.Y.J, Tokyo. Japan
}

ABSTRACT

\begin{abstract}
Children with asthma usually become asymptomatic by the time they reach age $20 \mathrm{y}$. To clarify the immunologic mechanisms responsible for this phenomenon, we studied patients in remission and others who still had frequent asthma attacks. Patients were grouped by clinical status, and three variables were measured: serum levels of IgE, production of IL 4 and interferon (IFN)- $\gamma$, and the activation of $\mathrm{T}$ cells induced by Dermatophagoides farinae (Df) antigen. Df-induced activation of ' $T$ cells (as measured by antigen-induced II 2 responsiveness) or II 2 synthesis itself was induced in patients with active asthma but not in normal subjects. These responses were much weaker in patients in remission. When stimulated by Df antigen in vitro, lymphocytes from patients with active asthma produced much more IL4 than did the cells from normal subjects, and cells from patients in remission produced only a small amount. In contrast, under similar conditions lymphocytes from patients with active asthma produced less IFN- $\gamma$ than did the cells from normal subjects. Production of IFN- $\gamma$ stimulated by Df antigen was high in patients in remission but not in normal subjects. Thus, upregulated IFN- $\gamma$ production after exposure to Df antigen might
\end{abstract}

Over the last two decades, the prevalence of asthma has increased dramatically, as have asthma-related hospitalization rates and mortality $(1-4)$. One widely recognized but poorly understood characteristic of asthma in children is that it often disappears during adolescence (12-25 y old); from 20 to $70 \%$ of these patients become largely or totally asymptomatic (5-7). The immunologic mechanisms responsible for this phenomenon are not known. Cells that are primed by allergens and present antigens can induce at least two kinds of 'Th cells (Th1

Received April 26, 1994; accepted March 9. 1995

Correspondence: 'Takeshi Noma M.D., Department of Pediatrics. Saitama Medical School. 38 Morohorgo. Moroyama, Iruma-gun, Saitama 350-(4). Jipan.

Supported in part by a grant from the Ministry of Fducation. Culture and Science, Japan. reduce II 4 secretion, which would suppress IgE production and would improve clinical status. Df antigen may suppress Dfinduced allergic responses in patients with asthma in remission. (Pediatr Res 38: 187-193, 1995)

\author{
PI, propidium iodide \\ Abbreviations \\ $\left[{ }^{3} \mathbf{H}\right] \mathbf{T} \mathbf{R}$, tritiated thymidine \\ IFN- $\gamma$, interferon $\gamma$ \\ Df, Dermatophagoides farinae \\ Con A, concanavalin A \\ RAST, radioallergosorbent test \\ ELISPOT, enzyme-linked immunospot assay \\ PBMC, peripheral blood mononuclear cell \\ r-II, recombinant IL \\ Th, helper $T$ cells \\ $\mathbf{F E V}_{\mathbf{1}}$, forced expiratory volume in $1 \mathrm{~s}$ \\ LSQ, lysing staining quenching \\ ds, double-stranded \\ ss, single-stranded
}

and Th2) in animals $(8,9)$. In allergic reactions, activated Th2 cells are involved in immediate responses, and $\mathrm{Ih} 1$ cells mediate delayed responses. The Th2 -specific cytokine II.4 induces $\lg \mathrm{F}$ production by inducing class switch and promotes the expression of low affinity Fce receptor II (10-12). Th1specific IFN- $\gamma$ and Th2-specific II 4 act in a reciprocal manner. IFN- $\gamma$ inhibits IL4-induced IgE production, and II 4 also inhibits IFN- $\gamma$ production $(13,14)$. In contrast, Th 1 cells activated by allergens can produce IL2. In patients with atopic diseases, the activated Th cells respond to II 2 in an autocrine or paracrine manner and then participate in allergic responses mediated by lymphokines $(8,9)$. We studied the relationship between clinical improvement in patients with bronchial asthma and the following phenomena: changes in the activation 
of T cells stimulated by Df; IL4 and IFN- $\gamma$ production; and serum IgE levels. The data reveal a close correlation between improvement in clinical status and changes in IL 2 responsiveness. This improvement was also associated with changes in the ratio of IFN- $\gamma$ :IL4 synthesis observed after short-term, antigen-specific restimulation of PBMC in vitro.

\section{MATERIALS AND METHODS}

Subjects. Lymphocytes were isolated from samples of blood taken from 40 Japanese patients with bronchial asthma (Table 1). Eight age-matched healthy subjects were used as the control group. Patients with active disease had recurrent asthma attacks, and positive immediate skin reactions (as defined by an immediate wheal response to a skin prick test) to house dust mite and Df antigen (mite 1, Torii \& Co., Ltd. Tokyo, Japan). Serum $\operatorname{IgE}$ scores against mite antigen (15), as determined by RAST, varied from 1 to 4 . The diagnostic criteria for bronchial asthma were those defined by the American Thoracic Society. None of the patients was having an asthma attack at the time of the examination, and none was taking oral corticosteroids or anti-allergic agents such as ketotifen (16). The subjects were divided into three groups. Patients in group I were in complete remission. They were either disease-free (approximately 74\%), or had had fewer than two or three mild asthma attacks per year over the previous 2 y without any medication. Patients in group II were in partial remission. They had had at least one, but fewer than two or three, mild asthma attacks per year over the previous 2 y despite medication. They were taking 15-20 $\mathrm{mg} / \mathrm{kg} /$ day of theophylline, or a $\beta_{2}$-agonist, or both, either continuously or intermittently. Patients in group III had active disease. They suffered more than 10 mild or moderate attacks per year, despite medication such as theophylline, a $\beta_{2}$-agonist, anti-allergic agents such as ketotifen, or some combination thereof. The severity of acute exacerbations of asthma and the severity of the disease were estimated according to the Guidelines for the Diagnosis and Management of Asthma, in the National Asthma Education Program; Expert Panel Report of the National Institutes of Health, USA. A mild attack was defined as normal alertness, no dyspnea or mild dyspnea (patient was able to speak in complete sentences), no retractions or mild intercostal retractions, good skin color, wheezing at the end of expiration only, and a peak expiratory flow rate or $\mathrm{FEV}_{1}$ that was $70-90 \%$ of the predicted or personal best. $\mathrm{FEV}_{1}$ did not differ significantly among the groups (Table 1). Before the study, levels of severity among patients in groups I and II were similar to those in patients in group III with mild or moderate, but not severe, asthma. Characteristics of the groups are shown in Table 1. Informed consent was obtained from each patient or from the patient's parents.

Staining/quenching solution. A stock solution of PI (Sigma Chemical Co., St. Louis MO, $0.5 \mathrm{mg} / \mathrm{mL}$ in $4.9 \%$ EDTA) was prepared, and $1.5 \mathrm{~mL}$ of this solution were diluted with $7.5 \mathrm{~mL}$ of EDTA solution (4.9\%, pH 7.0, Wako Pure Chemical Industries Inc., Japan). It was then added to $1.5 \mathrm{~mL}$ of Triton X-100 (8\%, vol/vol, Wako Pure Chemical Industries Inc., Japan) to lyse the lymphocytes. Drawing ink $\left(0.1 \mathrm{~mL}\right.$ of a $2^{10}$-fold dilution, Leitz, Wetzlar) was included to quench background fluorescence. This solution was kept at $-20^{\circ} \mathrm{C}$ and was called LSQ medium.

The assay with LSQ medium is based on the observation that living cells contain dsDNA immediately after division, but dead cells contain mainly ssDNA. In LSQ medium, PI attaches to dsDNA rather than to ssDNA derived from the cells lysed by Triton X-100. This difference in the affinity of PI allows one to count the living cells. The ink in the LSQ medium can suppress the background fluorescence of PI.

Assay of T cell responsiveness to $I L 2$. The growth of T cells incubated with an antigen and then exposed to IL2 was taken as an index of their responsiveness to IL2. The intensity of fluorescence of dsDNA was measured $(17,18)$. In brief, $1 \times$ $10^{6}$ mononuclear cells, separated from heparinized blood by centrifugation on a Ficoll-Hypaque (Pharmacia, Uppsala, Sweden) density gradient (19), were cultured in the presence of Df antigen or $5 \mu \mathrm{g} / \mathrm{mL}$ of Con A (Sigma Chemical Co., St. Louis, MO), and suspended in $1 \mathrm{~mL}$ of RPMI 1640 medium containing $40 \mu \mathrm{g} / \mathrm{mL}$ gentamicin and $10 \%$ heat-inactivated

Table 1. Characteristics of the study groups

\begin{tabular}{|c|c|c|c|}
\hline \multirow[b]{2}{*}{ Characteristic } & \multicolumn{3}{|c|}{ Group } \\
\hline & I. Complete remission & II. Incomplete remission & III. No remission \\
\hline No. of patients & 14 & 11 & 15 \\
\hline $\operatorname{Sex}(M / F)$ & $5 / 9$ & $9 / 2$ & $10 / 5$ \\
\hline \multicolumn{4}{|l|}{ Age (y) } \\
\hline Mean $\pm \mathrm{SD}$ & $18.3 \pm 6.7$ & $18.9 \pm 4.2$ & $16.2 \pm 6.5$ \\
\hline Range & $10-27$ & $14-26$ & $10-32$ \\
\hline Disease severity & Disease-free or mild & Mild & Mild or moderate \\
\hline Attack frequency (attacks/y) ${ }^{a}$ & $\begin{array}{l}\text { None (approximately } 3 / 4 \text { ) or less } \\
\text { than } 2 \text { or } 3 \text { mild attacks }\end{array}$ & $\begin{array}{l}\text { At least one but less than } 2 \text { or } \\
3 \text { mild attacks }\end{array}$ & $\begin{array}{l}\text { More than } 10 \text { mild or moderate } \\
\text { attacks }\end{array}$ \\
\hline Medication" & - & + (intermittent or persistent) & + (persistent) \\
\hline Serum IgE (lU/ml) & $679 \pm 115^{b}$ & $887 \pm 214$ & $1455 \pm 316$ \\
\hline Df-IgE RAST score ${ }^{c}$ & $3.33 \pm 0.33$ & $3.36 \pm 0.20$ & $3.44 \pm 0.18$ \\
\hline $\mathrm{FEV}_{1}(\%)$ & $94.4 \pm 3.2^{b}$ & $96.7 \pm 3.4$ & $90.5 \pm 4.1$ \\
\hline
\end{tabular}

Eight age-matched healthy subjects with no symptoms of allergy were used as the control group (age range: $12-25$ y).

a Per year over the previous $2 \mathrm{y}$.

${ }^{b}$ Mean value $\pm \mathrm{SE}$.

c As defined by 4 grade (score 4 includes more than 4 ).

${ }^{*} p<0.05$ (compared with group III). 
pooled human serum in a culture tube (Falcon Plastic 2054). After $5 \mathrm{~d}$ in culture $\left(37^{\circ} \mathrm{C}, 10 \% \mathrm{CO}_{2}\right)$, the medium was replaced with fresh medium, and the cells were divided into six aliquots in 96-well flat-bottom microplates (Nunc, Roskiled, Denmark). The cells were cultured for $3 \mathrm{~d}$ more in the presence of 0.5 unit/mL of r-IL2 (Takeda Co. Ltd., Tokyo, Japan) (18). Then, $50 \mu \mathrm{L}$ of the LSQ medium were added to the cell suspension, and the mixture was kept for $2 \mathrm{~h}$ at $37^{\circ} \mathrm{C}$. PI (3,8-diamino-5-[3-(diethylmethylammonio)propyl]-6-phenylphenanthridinium diiodide) methiodide) was added to the lysed lymphocytes to stain dsDNA but not ssDNA. The medium's fluorescence was quenched by the addition of drawing ink in the LSQ medium. The intensity of the fluorescence (long-pass filter, $580 \mathrm{~nm}$ ) was determined for each well with Leitz Patimed equipment (Leica). The index of responsiveness of T cells to IL2 was computed as follows $(17,18)$ : responsiveness $=$ (intensity of fluorescence with IL2 - intensity of fluorescence with LSQ medium alone)/(intensity of fluorescence without IL2 - intensity of fluorescence with LSQ medium alone). The coefficient of variation of the results of PI staining was small (less than 2.3\%).

IL2 production and assay. Lymphocytes $\left(10^{6}\right.$ cells $\left./ \mathrm{mL}\right)$ stimulated with Df $(10 \mu \mathrm{g} / \mathrm{mL})$ were cultured for $2 \mathrm{~d}$, and then the supernatant was collected. IL2 activity was assayed with the IL2-dependent CTLL line according to the method of Gillis et al. (20). Test supernatant was added to a final concentration of $50 \%$ to cultures containing $5 \times 10^{3}$ CTLL cells in a total volume of $100 \mu \mathrm{L}$. Approximately $24 \mathrm{~h}$ later, $0.5 \mu \mathrm{Ci}$ of $\left[{ }^{3} \mathrm{H}\right]$ thymidine was added. Cultures were harvested $16 \mathrm{~h}$ later. One unit of IL2 was defined as the amount obtained from a standard curve of CTLL cell proliferation with r-IL2. The incorporated radioactivity was measured by liquid scintillation counting. The CTLL cells were allowed to propagate in RPMI 1640 medium supplemented with 10\% FCS and IL2. When a MAb against human IL2 is added to the supernatant of cultures of lymphocytes taken from patients and stimulated with Df, CTLL indicator cells do not grow (21). This indicates that IL2, and no other lymphokine, was the active factor being assayed. The sensitivity of this assay was $0.02 \mathrm{unit} / \mathrm{mL}$.

Counting of cells producing $\boldsymbol{I L 4}$. Mononuclear cells $(1 \times$ $\left.10^{6}\right)$ were added to $1 \mu \mathrm{g} / \mathrm{mL}$ of Df antigen or to $5 \mu \mathrm{g} / \mathrm{mL}$ of Con A (Sigma Chemical Co., St. Louis, MO) and suspended in $1 \mathrm{~mL}$ of RPMI 1640 medium containing $40 \mu \mathrm{g} / \mathrm{mL}$ of gentamicin and $10 \%$ heat-inactivated pooled human serum in a culture tube (Falcon Plastic 2054), and cultured for $3 \mathrm{~d}\left(37^{\circ} \mathrm{C}\right.$, $\left.10 \% \mathrm{CO}_{2}\right)$. An ELISPOT assay was done, as reported elsewhere $(22,23)$, to evaluate the ability of these cells to produce IL4. Briefly, 96-well microplates (Linbro, Flow Laboratories, Inc. MacLean, VA) were coated overnight at $4^{\circ} \mathrm{C}$ with a purified MAb against IL4 (380-1, Ono Chemical Industries, Osaka, Japan) at a concentration of $30 \mu \mathrm{g} / \mathrm{mL}(100 \mu \mathrm{L} /$ well $)$. Control wells were coated with PBS containing 5\% FCS. All wells were then blocked with $200 \mu \mathrm{L}$ of $0.25 \%$ gelatin (Wako Pure Chemical Industries, Ltd., Tokyo, Japan) in PBS for $1 \mathrm{~h}$ at $37^{\circ} \mathrm{C}$. Df-stimulated or unstimulated cells $\left(1 \times 10^{3}\right.$ to $1 \times 10^{5}$ cells/well) resuspended in RPMI 1640 containing $3 \%$ FCS were added to each well $(100 \mu \mathrm{L} /$ well $)$ and incubated for $16 \mathrm{~h}\left(37^{\circ} \mathrm{C}, 10 \% \mathrm{CO}_{2}\right)$. The cells were washed three times with
PBS and then incubated in 1\% BSA-PBS for $2 \mathrm{~h}$ at room temperature with $100 \mu \mathrm{L}$ of a rabbit polyclonal antibody against human IL4 (4 $\mu \mathrm{g} / \mathrm{mL}$, BL-4, Genzyme Corp., Boston, MA). The plates were then washed three times with PBS and incubated in $1 \%$ BSA-PBS $(100 \mu \mathrm{L} /$ well) with alkaline phosphatase-conjugated anti-rabbit IgG obtained from goats (diluted 1:1000, 65-6122, Zymed Laboratories, Inc. San Francisco, $\mathrm{CA}$ ) for $2 \mathrm{~h}$ at room temperature. The plates were then washed with PBS three times and refilled with $100 \mu \mathrm{L}$ of a solution of $1 \mathrm{mg} / \mathrm{mL}$ alkaline phosphatase substrate, 5-bromo-4-chloro-3indolyl phosphate (Sigma Chemical Co., St. Louis MO) dissolved at $40^{\circ} \mathrm{C}$ in $0.6 \%$ (wt/vol) agarose (Electlan, 44250, $\mathrm{BDH}$, Poole, England) containing 0.1 M 2-amino-2-methyl-1propanol, $0.02 \%$ (vol/vol) Triton X-405 (BDH), and $5.0 \mathrm{mM}$ $\mathrm{MgCl}_{2}$. Spots representing single IL4-secreting cells that developed during $4 \mathrm{~h}$ of incubation at $37^{\circ} \mathrm{C}$ were counted with an inverted microscope. The specificity of the ELISPOT assay for detecting IL4-secreting cells was determined by inhibition with soluble antibody against IL4.

IFN- $\gamma$ production and assay. Mononuclear cells $\left(1 \times 10^{6}\right)$ were added to graded doses $(0.1,1.0,10.0 \mu \mathrm{g} / \mathrm{mL})$ of $D f$ or to a $5 \mu \mathrm{g} / \mathrm{mL}$ dose of Con $\mathrm{A}$, and suspended in $1 \mathrm{~mL}$ of RPMI 1640 medium containing $40 \mu \mathrm{g} / \mathrm{mL}$ of gentamicin and $2 \%$ heat-inactivated pooled human serum in a culture tube (Falcon Plastic 2054). Then the cells were cultured for $5 \mathrm{~d}$ $\left(37^{\circ} \mathrm{C}, 10 \% \mathrm{CO}_{2}\right)$. Culture supernatants from the cells were harvested and assayed for IFN- $\gamma$ with a slightly modified version of a solid-phase ELISA reported elsewhere (24). Briefly, 96-well microtiter plates (Linbro, Flow Laboratories, Inc., MacLean, VA) were coated with $100 \mu \mathrm{L} /$ well of rabbit antibody against human IFN- $\gamma$ (PIF-3, Hayashibara Biochemical Laboratories, Inc., Okayama, Japan) at $1 \mu \mathrm{g} / \mathrm{mL}$ each in $\mathrm{pH} 9.6,0.1 \mathrm{M} \mathrm{NaHCO}_{3}$ buffer overnight at $4^{\circ} \mathrm{C}$ in a humidified box. The wells were washed and then blocked with $150 \mu \mathrm{L}$ of $0.25 \%$ gelatin (Wako Pure Chemical Industries, Ltd.). A total of $100 \mu \mathrm{L}$ of undiluted culture supernatant per well were assayed. After $16 \mathrm{~h}$ of incubation at $4^{\circ} \mathrm{C}$, the wells were emptied and washed three times. Then $1 \mu \mathrm{g} / \mathrm{mL}$ of mouse MAb against human IFN- $\gamma$ (MIF-3, Hayashibara Biochemical Laboratories, Inc., Okayama, Japan) was added to the wells. They were then incubated at room temperature for $1 \mathrm{~h}$. After three washes, goat biotinylated antibody against mouse $\mathrm{IgG}$ (Tago, Inc., Burlingame, CA; diluted 1/3000) was added and allowed to incubate for $1 \mathrm{~h}$. After three washes with PBS, streptavidin-conjugated horseradish peroxidase (Life Technologies, Inc., Gaithersburg, MD) was added to each well, and the plates were incubated at room temperature for $20 \mathrm{~min}$. A total of $100 \mu \mathrm{L}$ of $O$-phenilenediamine (Life Technologies, Inc.) substrate solution was added to the wells after six washes with PBS/Tween. Absorbance at $492 \mathrm{~nm}$ was read with an ELISA reader (Bio-Tek Instruments, Inc., Burlington, VT). Purified human IFN- $\gamma$ (Japan Chemical Research Pharmaceuticals Co., Ltd., Kobe, Japan) was used as a standard. Results are expressed as units of IFN- $\gamma / \mathrm{mL}$ of supernatant with reference to a standard IFN- $\gamma$. The sensitivity of this sandwich ELISA assay was $1 \mathrm{unit} / \mathrm{mL}$.

The greatest difference in IFN- $\gamma$ activity between unstimulated cells and Df-stimulated cells from patients with active 
asthma was observed when the concentration of human serum used in the culture medium was $2 \%$. Therefore, this concentration was used in the culture for IFN- $\gamma$ production.

IgE measurements. Total IgE levels in serum were measured with a solid-phase ELISA as reported elsewhere (25). Levels in serum of specific IgE against Df antigen were determined by RAST (15).

Data analysis. The data were analyzed with the two-tailed $t$ test.

\section{RESULTS}

Evaluation of $D f$-induced responsiveness of $T$ cells to IL2 and of the production of IL2 by lymphocytes from patients with asthma. Lymphocytes obtained from patients in group III induced Df-specific IL2 responses, in a Df dose-dependent manner (Fig. 1). These responses were much weaker when they were induced by lymphocytes from normal subjects $(p<0.05$, Fig. 1). Responses induced by lymphocytes from patients in group II were also stronger than those induced by lymphocytes from normal subjects. In contrast, the responses induced by lymphocytes from patients in group I were similar to those induced by lymphocytes from normal subjects (Fig. 1). In groups I and II, IL2 responses were weak, the patients had fewer symptoms, and the symptoms were not severe. Older patients who still had symptoms (group III) were responsive. The intensity of the response was not related to age (data not shown). IL2 production by lymphocytes from patients in group III was much greater than that of lymphocytes from normal subjects. It was also greater than that of lymphocytes from patients in remission (groups I and II, Fig. 2). Collectively, the data indicate that $T$ cell responses induced by Df were markedly weaker in the patients in remission than in those with active disease.



Figure 1. Abnormally low responsiveness to IL2, induced by Df antigen in patients with asthma in remission. PBMC $\left(1 \times 10^{6}\right)$ were added to serial doses of Df antigen. After $5 \mathrm{~d}$ in culture $\left(37^{\circ} \mathrm{C}, 10 \% \mathrm{CO}_{2}\right)$, the media were replaced with fresh media, and the cells were cultured for $3 \mathrm{~d}$ more in the presence of r-IL2. At the end of the culture, LSQ medium was added to the cell suspension. The fiuorescence intensity was used as an index of responsiveness to IL2. Data shown are means $\pm \mathrm{SE}$. $\mathrm{O}$, complete remission (group I, $n=14$ ); partial remission (group II, $n=11$ ); $\bullet$ no remission (group III, $n=15$ ); $\diamond$, age-matched normal subjects $(n=7) ;{ }^{*} p<0.01$

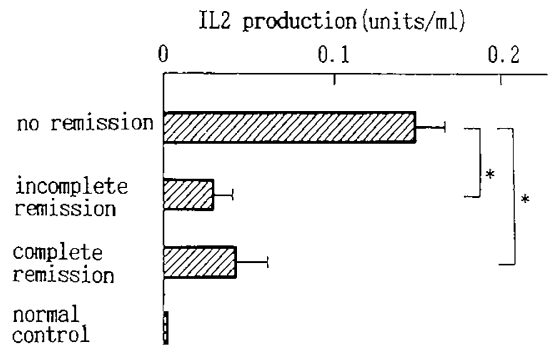

Figure 2. IL2 production by Df-stimulated lymphocytes from patients in remission. Df-stimulated PBMC $(10 \mu \mathrm{g} / \mathrm{mL})$ were cultured for $2 \mathrm{~d}$, and then activity of IL2 in the supernatant was assayed with the IL2-dependent CTLL cell line. No remission: group III, $n=15$; incomplete remission: group II, $n=$ 11; complete remission: group I, $n=14$; normal control: age-matched normal subjects, $n=4 ;{ }^{*} p<0.001$. Data shown are means \pm standard errors. Values of normal control subjects are less than the sensitivity of the assay.

Production of ILA by lymphocytes from patients. The number of cells producing IL4 was approximately 5-fold higher in patients with active asthma (group III) than in nonasthmatic subjects (Fig. 3). The production of IL4 induced by Df in patients with active asthma was dose-dependent; $1 \mu \mathrm{g} / \mathrm{mL}$ IL4 induced the maximal response (data not shown). Con A also induced production of cells that secreted IL4, up to a number similar to the Df-induced spot number. There were no differences in the spot numbers between lymphocytes from patients (36.3 \pm 14.3 (SE) spots $/ 10^{5}$ cells, $n=9$ ) and from normal individuals $\left(42.6 \pm 4.4(\mathrm{SE})\right.$ spots $/ 10^{5}$ cells, $\left.n=6\right)$ when stimulated with Con A. After in vitro stimulation with Df antigen, the frequency of Df-reactive cells producing IL4 from patients in remission (groups I and II) was significantly lower than that from patients with active disease (group III, Fig. 3). Thus, the ability of lymphocytes from patients in remission to secrete IL4 when stimulated with Df antigen was downregulated.

Production of IFN- $\gamma$ by lymphocytes from patients. In the absence of in vitro stimulation with Df antigen, production of

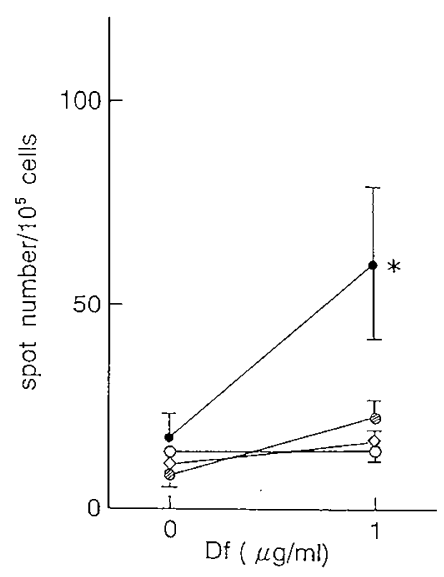

Figure 3. Generation of IL4-secreting cells from Df-stimulated lymphocytes in patients with bronchial asthma in remission. Df-stimulated cells were cultured for $72 \mathrm{~h}$, then the spot indicating generation of a single IL4-secreting cell was studied for another $16 \mathrm{~h}$. Maximal production of IL4 by PBMC from group III patients was elicited by $1 \mu \mathrm{g} / \mathrm{mL}$ of Df antigen. Data shown are means \pm SE. $\bigcirc$, complete remission $(n=14)$; partial remission $(n=11)$; -, no remission $(n=15) ; \diamond$, age-matched normal subjects $(n=7) ;{ }^{*} p<0.01$ (compared with normal subjects and patients in complete or partial remission). 
IFN- $\gamma$ by lymphocytes from patients and from normal subjects was essentially equivalent (Fig. 5). In the presence of Df antigen, the production of IFN- $\gamma$ by lymphocytes from patients with active disease (group III) was dose-dependently inhibited (Figs. 4 and 5). This was not true of lymphocytes from normal subjects. Production of IFN- $\gamma$ by lymphocytes from the patients with active asthma who were allergic solely to Df was not inhibited by ovalbumin or Japanese cedar antigen (Fig. 4). In contrast, production of IFN- $\gamma$ by lymphocytes from patients allergic solely to ovalbumin or Japanese cedar antigen was lower after stimulation with these substances (data not shown). These results indicate that Df-induced inhibition of the production of IFN- $\gamma$ in patients with asthma was specific to the antigen. Moreover, IFN- $\gamma$ production by cells from patients in complete remission (group I) was markedly higher after antigen-driven restimulation (Fig. 5), but that was not true of IFN- $\gamma$ production by cells from patients with active disease (group III) or in partial remission (group II). After in vitro stimulation with Con A, IFN- $\gamma$ synthesis did not differ among the groups (Fig. 5). Collectively, the data indicate that after exposure to Df antigen the IFN- $\gamma$ responses of patients in complete remission can increase.

Serum IgE levels in asthmatic subjects. Total serum IgE levels of patients in complete remission were significantly lower than those of patients with active disease (Table 1). Df-specific IgE levels in asthmatic subjects correlated only weakly with clinical improvement (data not shown). However, there were no statistically significant differences in RAST scores (Table 1).

\section{DISCUSSION}

The highest incidence of bronchial asthma is during the first several years of life (5). Asthma is rarely diagnosed during adolescence and almost all patients become asymptomatic by

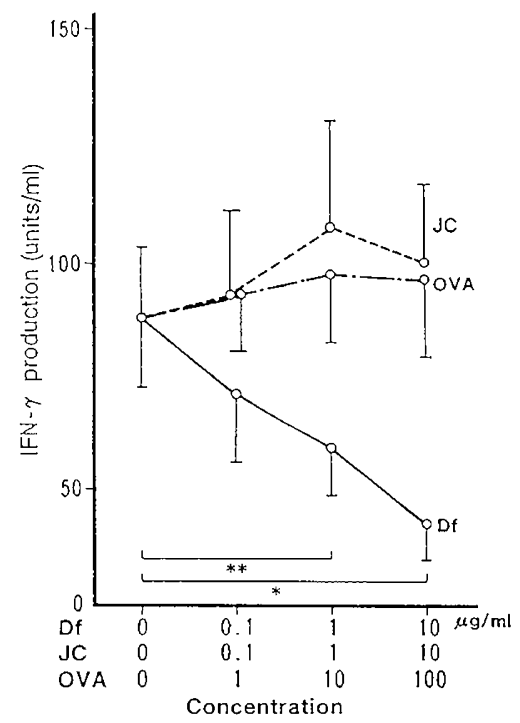

Figure 4. Antigen-specific inhibition of IFN- $\gamma$ production by Df-stimulated lymphocytes from patients with active asthma. PBMC $\left(1 \times 10^{6}\right)$ were added to graded doses of Df antigen, ovalbumin (OVA), or Japanese cedar $(J C)$ antigen and cultured for $5 \mathrm{~d}$. The culture supernatants were assayed for IFN- $\gamma$ activity with a solid-phase ELISA. Data shown are means $\pm \operatorname{SE}(n=6)$.

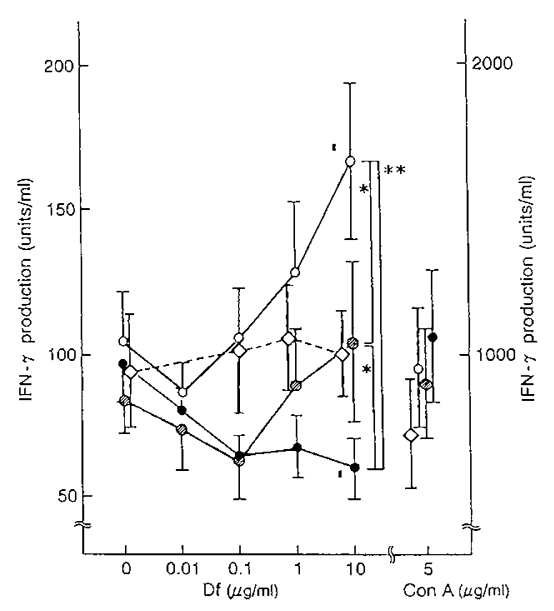

Figure 5. IFN- $\gamma$ production by Df-stimulated lymphocytes from patients in remission. PBMC $\left(1 \times 10^{6}\right)$ were added to graded doses of Df or Con A and cultured for $5 \mathrm{~d}$. The supernatants were assayed for IFN- $\gamma$ activity. Data shown are means $\pm \mathrm{SE} . \mathrm{O}$, complete remission (group I, $n=14$ ); partial remission (group II, $n=11$ ); $\bullet$, no remission (group III, $n=15$ ); $\diamond$, age-matched normal subjects $(n=8)$; ${ }^{*} p$ not significant; ${ }^{* *} p<0.01 ; \# p<0.05$ (compared with unstimulated cells and cells from normal subjects that were stimulated with $10 \mu \mathrm{g} / \mathrm{mL}$ Df antigen).

that time. In almost all children and young adults with asthma, mite antigen skin tests are positive $(5,7)$. In contrast, asthma first diagnosed later in life (after the age of $40 \mathrm{y}$ ) often has no clear relationship to atopy and is generally associated with persistent symptoms (1). To better understand the immunologic mechanisms of childhood asthma attacks caused by exposure to mite antigen, we evaluated a number of immunologic factors in adolescents who were in remission and in others who still had frequent asthma attacks.

In vitro testing of $\mathrm{T}$ lymphocytes activated by antigens is an important way to study $\mathrm{T}$ cell-dependent responses in allergic subjects (8-11). Previously, the presence and activity of such lymphocytes were studied primarily via measurement of proliferation of freshly derived PBMC in response to allergens $(26,27)$. More recently, cytokine production in response to allergen-specific stimulation has been measured (28). This approach, in which freshly derived normal $\mathrm{T}$ cells are used instead of long-term $\mathrm{T}$ cell clones, has generally yielded weak responses, so the results are difficult to compare with those from $\mathrm{T}$ cells freshly derived from nonatopic and allergic subjects. Acquisition of IL2 responsiveness by allergenstimulated PBMC is essential for T cell activation (8--14). We previously reported that allergens can induce responsiveness to IL2 in T lymphocytes freshly derived from allergic subjects, but not in those derived from normal subjects $(18,29-32)$. We showed that this sensitive measure of in vitro $\mathrm{T}$ cell reactivation could be used to identify sensitizing allergens and to monitor clinical activity of the disease $(17,18,29,30)$.

In this study, Df-induced $\mathrm{T}$ cell activation (as measured by IL2 responsiveness) occurred in PBMC freshly derived from patients with asthma, after short-term stimulation with Df antigen; but it did not occur in PBMC from normal subjects. The Df-specific responses to IL2 in cells from patients in complete or partial remission were very weak. Similarly, when measured in vitro, IL2 production induced by Df was signifi- 
cantly lower in samples from those patients than in samples from patients with active disease. Cells stimulated with Con A became responsive to IL2; they divided approximately 2-3fold in $8 \mathrm{~d}$. Df-activated lymphocytes from patients also became responsive to IL2, and the number of cells increased in the same fashion. In contrast, unstimulated lymphocytes cultured for $5 \mathrm{~d}$ did not proliferate (as measured by the intensity of fluorescence), and the number of living cells did not increase, even when r-IL2 was added to the cell suspension over a 3-d-long second culture. In contrast, unstimulated cells took up more $\left[{ }^{3} \mathrm{H}\right] \mathrm{TdR}$ when stimulated with r-IL2 than without $\mathrm{r}$-IL2. Thus, IL2 responsiveness (as measured by $\left[{ }^{3} \mathrm{H}\right] \mathrm{TdR}$ uptake) increased to an degree similar to that seen in the cells activated by antigen. This is why the $\left[{ }^{3} \mathrm{H}\right] \mathrm{T} d \mathrm{R}$ uptake method for evaluating antigen specificity of the induced IL2 responsiveness of activated cells could not substitute for counting of cells stained by PI $(17,18)$.

IL4 has been shown to be essential for IgE production both in animals and in humans (33-35). The ratio of IL4:IFN- $\gamma$ synthesis after exposure to an antigen may determine whether that exposure causes hypersensitivity or tolerance. Consequently, we directly examined the capacity of fresh PBMC from normal and asthmatic subjects to synthesize IL4 and IFN- $\gamma$ after antigen-specific restimulation in vitro. The data revealed very high levels of IL4 synthesis and low levels of IFN- $\gamma$ synthesis in patients with active asthma (group III). In contrast, patterns of cytokine synthesis in patients who were in complete or partial remission were similar to those in normal subjects. This association between the patterns of in vitro cytokine synthesis in patients in remission and improvement in their clinical status is intriguing; it provides strong, albeit indirect, support for the hypothesis that the ratio of IL4:IFN- $\gamma$ synthesis by antigen-specific $\mathrm{T}$ cells affects the intensity of hypersensitivity.

When stimulated with Df antigen, the cells from patients with active disease produced less IFN- $\gamma$ and more IL4 than did nonactivated cells. The Df-induced inhibition of IFN- $\gamma$ production by cells from patients with active disease was blocked by anti-lL4 antibody, and production of IFN- $\gamma$ returned to a level similar to that of nonactivated cells (our unpublished data). Anti-IL4 antibody did not influence IFN- $\gamma$ production by nonstimulated cells (our unpublished data). Df-induced production of IFN- $\gamma$ by lymphocytes from normal subjects was suppressed by recombinant IL4 in a dose-dependent manner (our unpublished data). One reason for the decrease in Dfinduced production of IFN- $\gamma$ may be secretion of regulatory cytokines, such as IL4, by Df-reactive cells. The ability of IL4 and IFN- $\gamma$ to cross-regulate one another's synthesis $(13,36)$ is still a topic of much debate and has been studied in animals and humans. However, it is tempting to speculate that changes in the balance of cytokine synthesis in adolescents with asthma may improve their clinical status and decrease $\operatorname{IgE}$ production.

An intriguing finding of this study was the high level of antigen-stimulated production of IFN- $\gamma$ by lymphocytes obtained from Df-insensitive patients in complete remission (group I). These data suggest that clinical unresponsiveness reflects not anergy but active inhibition of $\operatorname{IgE}$ induction, which may be caused by antigen-driven processes such as IFN- $\gamma$ synthesis. One interpretation of our data are that $\mathrm{CD}^{+} \mathrm{T}$ cells shift from Th2 type to Th1 type $(9,12,13)$. The mechanisms of such a shift remain unclear. However, when stimulated with a specific antigen, a resting $\mathrm{CD}^{+}{ }^{+} \mathrm{T}$ perentiates into a pluripotential Th0 cell. Under the influence of additional factors, such as exogenous lymphokines and costimulatory molecules expressed by cells that present antigens, the Th0 cell differentiates into a mature Th1 or Th2 effector cell (37). Cytokines such as IL12 (38) and IFN- $\gamma$ (39), or a difference in the cells that present antigens $(40,41)$, or both, may be involved in the mechanisms by which Th 1 cells predominate in patients in complete remission.

In this study, T cell activation (as determined by Df-induced responsiveness to IL2) was low in patients in remission. This finding conflicts with the production of IFN- $\gamma$ by these cells. We did not determine whether the frequency of Df-reactive cells in the PBMC of these patients was similar to that in normal subjects, or was lower than that in patients with active disease. However, in patients in remission Df antigen may be able to induce Th1-type clonal anergy and to induce Th1-type clones that produce cytokines such as IFN- $\gamma$. This hypothesis is supported by the following finding: after antigen-presenting cells are activated, IL12 can increase the production of IFN- $\gamma$ in anergic cells without causing proliferation, and this production of IFN- $\gamma$ by anergic cells can occur even in the absence of IL12 (42). The cytokine IL12 is produced by macrophages and $\mathrm{B}$ cells (43). It stimulates the proliferation of $\mathrm{T}$ cells after they are activated, induces the production of IFN- $\gamma$ (38), and is important in predominantly Th1-like responses in T cells (44). We did not study IL12 receptors or the ability of cells from patients in remission to produce IL12. However, IL12 might cause Df-induced anergic cells to produce IFN- $\gamma$ without causing cell proliferation.

The effects of treatment with recombinant IFN- $\gamma$ in allergic disease are controversial. In one study, IFN- $\gamma$ did not inhibit IgE in vivo in patients with allergic rhinitis and had minimal effects in patients with atopic dermatitis (45). Administration of IFN- $\alpha$ and IFN- $\gamma$ to patients with hyper-IgE syndrome can transiently reduce $\operatorname{IgE}$ levels $(46,47)$. We found no direct evidence that IFN- $\gamma$ suppresses IL4-driven IgE production among patients in remission. However, in vitro suppression of $\operatorname{IgE}$ production by IFN- $\gamma(35,36,48)$ may be important in the treatment of allergic diseases such as mite antigen-induced asthma. The low level of IL2 responsiveness and subsequent changes in the pattern of cytokine production by Df-stimulated lymphocytes from patients with Df-induced asthma in remission might be used to lower IgE levels, which would suggest a strategy for the use of IFN- $\gamma$ to treat asthma.

Recombinant cytokines may become available for clinical studies. In the present study, production of IFN- $\gamma$ by Dfstimulated lymphocytes from patients with active asthma was low, but production by lymphocytes from patients in remission was high. These data indicate that recombinant IFN- $\gamma$ may be useful as an adjunct to immunotherapy in bronchial asthma. Work to be reported in the near future may define the clinical role of cytokines. 
Acknowledgments. The authors thank the late professor Kazuichi Maeda and Dr. Kent HayGlass for critical review and helpful discussions, M. Kobayashi for secretarial assistance, and Y. Nakamura, B.S., for technical assistance.

\section{REFERENCES}

1. Asthma-United States 1992 Morb Mortal Wkly Rep 41:733-735

2. Pedersen PA, Weeke ER 1992 Occurrence of asthma and non-infectious rhinitis in Denmark. Nord Med 107:119-121

3. Knottnerus JA, Metsemakers J, Hoppener P, Limonard C. 1992 Chronic illness in the community and the concept of "social prevalence." Fam Pract 9:15-21

4. Costello J 1991 Asthma: The problem and the paradox. Postgrad Med J 67(suppl 4): $1-5$

5. Burrows B 1987 The natural history of asthma. J Allergy Clin Immunol 80:373-377

6. Richard E 1987 Recent observations reflecting increases in mortality from asthma. J Allergy Clin Immunol 80:377-379

7. Matsui T, Baba M 1990 Death from asthma in children. Acta Paediatr Jpn 32:205-208

8. Yokota T, Arai N, de Vries J, Spits H, Banchereau J, Zlotnik A, Rennick D, Howard M, Takebe Y, Miyatake S, Lee F, Arai K 1988 Molecular biology of interleukin 4 and interleukin 5 genes and biology of their products that stimulate B cells, $\mathrm{T}$ cells and hemopoietic cells. Immunol Rev 102:137-145

9. Mosmann TR, Coffman RL 1989 TH1 and TH2 cells: Different patterns of lymphokine secretion lead to different functional properties. Annu Rev Immunol 7:145-173

10. Finkelman FD, Holmes J, Katona IM, Urban Jr JF, Beckmann MP, Park LS, Schooley KA, Coffman RL, Mosmann TA, Paul WE 1990 Lymphokine control of in vivo immunoglobin isotype selection. Annu Rev Immunol 8:303-330

11. Romagnani S 1990 Regulation and deregulation of human IgE synthesis. Immunol Today 11:316-321

12. Hodgkin PD, Yamashita LC, Seymour B, Coffman RL, Kehry MR 1991 Membranes from both $\mathrm{TH} 1$ and $\mathrm{TH} 2$ cell clones stimulate $\mathrm{B}$ cell proliferation and prepare $\mathrm{B}$ cells for lymphokine-induced differentiation to secrete lg. J Immunol 147:3696-3702

13. Maggi E, Parronchi P, Manetti R, Simonelli C, Plccinni MP, Rugiu FS, de Carll M Ricci M, Romagnani S 1992 Reciprocal regulatory effects of IFN- $\gamma$ and IL-4 on the in vitro development of human TH1 and TH2 clones. J Immunol 148:2142-2147

14. Yessel H, Johnson KE, Schneider PV, Wideman J, Terr A, Kasteleln, de Vries JE $1992 \mathrm{~T}$ cell activation inducing epitopes of the house dust mite allergen Der pl-specific CD4sup + T cell clones. J Immunol 148:738-745

15. Miyamoto T, Johansson SGO, Ito K, Horiuchi Y 1974 Atopic allergy in Japanese subjects: Studies primarily with radioallergosorbent test. J Allergy Clin Immunol 53:9-14

16. Noma T, Yoshizawa I, Baba M, Yata J, Akasaka T, Maeda K 1990 Effect of ketotifen on antigen-induced interleukin 2 (IL-2) responsiveness from patients with atopic dermatitis and/or bronchial asthma. Int J Immunopharmacol 12:269-277

17. Noma T, Yoshizawa I, Nakamura Y, Kawano Y, Nakajima T, Itoh M, Maeda K, Ikezawa Z, Baba M, Yata J 1991 A rapidly measuring technique for allergen-induced II2 responsiveness by lymphocytes using the propidium iodide-staining method: Detection of the etiological antigen in patients with allergic diseases. Jpn $J$ Allergol 41:1354-1366

18. Noma T, Yoshizawa I, Maeda K, Baba M, Yata J 1994 Initial events and T cell activation in lymphokine-mediated allergic responses in patients with hen egg allergy. Ann Allergy 73:76-84

19. Boyum A 1968 Separation of lymphocytes from blood and bone marrow. Scand J Clin Lab Invest 21:31-50

20. Gillis S, Ferm MM, Ou W, Smith KA 1978 T cell growth factor: Parameters of production and a quantitative microassay for activity. J Immunol 120:2027-2032

21. Mosmann TR, Cherwinski H, Bond MW, Giedlion MA, Coffman, RL. 1986 Two types of murine $\mathrm{T}$ cell clone. I. Definition according to profiles of lymphokine activities and secreted proteins. J Immunol 136:2348-2357

22. Sedgwick JD, Holt PG 1983 A solid-phase immunoenzymatic technique for the enumeration of specific antibody-secreting cells. J Immunol Methods 57:301-309

23. Ando DG, Ebling FM, Hahn BH 1986 Detection of native and denatured DNA antibody-forming cells by the enzyme-linked immunospot assay. Arthritis Rheum 29:1139-1146

24. Schreiber RD, Hicks LJ, Celada A, Buchmeier NA, Gray PW 1985 Monoclonal antibodies to murine $\gamma$-interferon which differentially modulate macrophage activation and anti-viral activity. J Immunol 134:1609-1618

25. Macy E, Kemeny M, Saxon A. 1988 Enhanced ELISA: How to measure less than 10 picograms of a specific protein (immunoglobin) in less than 8 hours. FASEB $J$ 2:3003-3007

26. Romagnani S, Biliotti G, Passaleva A, Ricci M. 1973 Mites and house dust allergy. III. In vitro lymphocyte transformation and precipitating antibody to house dust and mite (D. pteronyssinus) extract in atopic and non-atopic individuals. Clin Allergy 3:51-56

27. Black PL, Marsh DG 1980 Correlation between lymphocyte response and immediate hypersensitivity to purified allergen. J Allergy Clin Immunol 66:394-401

28. Rawle CF, Mitchell EB, Platts-Mills TAE 1984 T cell responses to the major allergen from the house dust mite Dermatophagoides pteronyssinus, antigen P1: Comparison of patients with asthma, atopic dermatitis, and perennial rhinitis. J Immunol 133:195201

29. Noma T, Yoshizawa I, Kawano Y, Itoh M, Baba M, Yata J 1987 Allergen-induced IL2 responsiveness in lymphocytes from patients with atopic dermatitis and/or bronchial asthma. Its chronological change and clinical significance. Jpn J Allergol 36:1075-1084

30. Yoshizawa I, Noma T, Kawano Y, Yata J 1989 Allergen-specific induction of IL2 responsiveness in lymphocytes from children with asthma. I. Antigen specificity and initial events of the induction. J Allergy Clin Immunol 84:246-255

31. Noma T, Yoshizawa I, Maeda K, Ichikawa K, Baba M, Yata J 1989 Allergen-specific induction of IL2 responsiveness in lymphocytes from children with asthma. II. Regulation of IL2 responsiveness by supernatants of normal lymphocytes. J Allergy Clin Immunol 84:256-262

32. Noma T, Kawano Y, Yoshizawa I, Mukouyama T, Baba M, Yata J 1990 Ovalubuminspecific induction of IL2 responsiveness in lymphocytes from patients with hen egg allergy and its regulation by the culture supernatant of normal lymphocytes. Ann Allergy 64:33-41

33. Finkelman FDIM, Katalona JF, Urban CM, Snapper J, Ohara J, Paul WE 1986 Suppression of in vivo polyclonal IgE responses by monoclonal antibody to the lymphokine BSF-1. Proc Natl Acad Sci USA 83:9675-9678

34. Coffman RL, Ohara J, Bond MW, Carty J, Zlotnik A, Paul WE 1986 B cell stimulatory factor- 1 enhances the IgE response of lipopolysaccharide-activated $B$ cells. J Immunol 136:4538 - 4541

35. Pene JF, Rousset F, Briere I, Chretien JY, Bonnefoy H, Spits T, Yokota N, Arai K, Banchereau J, de Vries J 1988 IgE production by normal human lymphocytes is induced by interleukin 4 and suppressed by interferons $\gamma$ and $\alpha$ and prostaglandin $E_{2}$. Proc Natl Acad Sci USA 85:6880-6884

36. Coffman RL, Carty J 1986 A T cell activity that enhances polyclonal IgE production and its inhibition by interferon- $\gamma$. J Immunol 136:949-954

37. Gajewski TF, Fitch FW 1991 Differential activation of murine TH1 and TH2 clones. Res Immunol 142:19-23

38. Germann T, Gately MK, Schoenhaut DS, Lohoff M Mattner F, Fischer S, Jin SC Schmitt E, Rude E 1993 Interleukin-12/T cell stimulating factor, a cytokine with multiple effects on T helper type 1 (TH1) but not on TH2 cells. Eur J Immunol 23:1762-1770

39. Gajewski TF, Joyce J, Fitch FW. 1989 Anti-proliferative effect of IFN- $\gamma$ in immune regulation. III. Differential selection of TH1 and TH2 murine helper T lymphocyte clones using recombinant IL2 and recombinant IFN- $\gamma$. J Immunol 143:15-22

40. Weaver CT, Hawrylowicz CM, Unanue ER. 1988 T helper cell subsets require the expression of distinct costimulatory signals by antigen-presenting cells. Proc Natl Acad Sci USA 85:8181-8185

41. Gajewski TF, Pinnas M, Wong T, Fitch FW. 1991 Murine TH1 and TH2 clones proliferate optimally in response to distinct antigen-presenting cell populations. J Immunol 146:1750-1758

42. Quill H, Bhandoola A, Trinchieri G, Haluskey J, Peritt D 1994 Induction of interleukin 12 responsiveness is impaired in anergic $\mathrm{T}$ lymphocytes. J Exp Med 179:1065-1070

43. D'Andrea AM, Rengaraju M, Valiante NM, Chehimi J, Kubin M, Aste M, Chan SH, Kobayashi M, Young D, Nickbarg E, Chizzonite R, Wolf SF, Trinchieri G 1992 Production of natural killer cell stimulatory factor (NKSF/IL12) by peripheral blood mononuclear cells. J Exp Med 176:1387-1398

44. Manetti R, Parronchi P, Giudizi MG, Piccini MP, Maggi E, Trinchieri G, Romagnani S 1993 Natural killer cell stimulatory factor (interleukin 12 [IL-12]) induces T helper type 1 (Th1)-specific immune responses and inhibits the development of IL-4 producing Th cells. J Exp Med 177:1199-1204

45. Li JTC, Yunginger JW, Reed CE, Jaffe HS, Nelson DR, Gleich GJ 1990 Lack of suppression of IgE production by recombinant interferon $\gamma$ : A controlled trial in patients with allergic rhinitis. J. Allergy Clin Immunol 85:934-940

46. Souillet G, Rousset F, de Vries JE 1989 Alpha interferon treatment of patient with hyper IgE syndrome. Lancet 1:1384

47. King CL, Gallin JI, Malech HL, Abramson SL, Nutman TB 1989 Regulation of immunogloublin production in hyperimmunoglobulin $\mathrm{E}$ recurrent-infection syndrome by interferon $\gamma$. Proc Natl Acad Sci USA 86:10085-10089

48. Pene J, Rousset F, Briere F, Chretien I, Paliard X, Banchereau J, Spits H, de Vries JE 1988 IgE production by normal human B cells induced by allo-reactive T cell clones is mediated by IL-4 and suppressed by IFN- $\gamma$. J Immunol 141:1218-1224 